\title{
Defining Sustainability: \\ A Challenge for the Next FOCUS
}

PAUL WACK

Paul W, Wack, A.I.C.P., is a professor at $\mathrm{Cal}$ Poly's CRP Department.

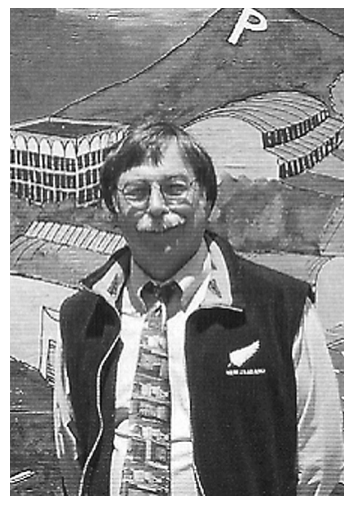

Paul at Cal Poly's Open House in 2004
Have you ever been stuck trying to respond to the question "what is "sustainability"? Many planners have a basic understanding of what they think this concept means, but have a difficult time articulating it through a succinct definition that generates at least a responsive nod appreciation for the attempt, especially among the general public. Paul Wack and FOCUS issue a challenge to see if anyone on this planet can offer such a definition for a concept that potentially possesses the necessary components to confront the evolving forces of climate change.

\section{Sustainability is not something to be defined, but something to be declared. It is an ethical guiding principle. \\ - Bert De Vries}

What is sustainability (or sustainable development)? Defining this "fuzzy" term has been an ongoing issue for years with little resolution. The range of definitions generated during the past two decades has been as mixed as the bargain bin at the local flea market. Of course the most common definition cited is the well known Bruntland Commission offering that sustainable development "meets the needs of the present without compromising the ability of future generations to meet their own needs", which is often criticized as being too simplistic and development-biased (Brundtland, 1987). Defining sustainability continues to be a challenge as the concept becomes increasingly integrated into planning education and practice (Gunder, 2006).

The challenge here is to encourage academics, practicing planners, and students to create a simple definition that does not require a dissertation to explain, but retains a touch of simplicity for ease of discussion.

For starters, I offer the following pseudo formula: $S=E^{3}+F^{7}$.

$\mathrm{S}$ means sustainability; $\mathrm{E}^{3}$ means economy, environment, and equity; and $\mathrm{F}^{7}$ means the future to at least the seventh generation.

I have considered adding " + NS 4 " to represent 'The Natural Step", which is the basis for APA's Policy Guide Planning for Sustainability (see http://www.planning.org/policyguides/sustainability.htm).

Send your "Sustainability Definition for Simplicity" entries by email to Paul Wack (pwack@calpoly. edu) before January 1, 2008. They should not exceed 100 words long. A panel of distinguished faculty and students will select the best three entries, which will be properly acknowledged and cited in next year's FOCUS. The authors of the winning entries will receive a life-long subscription to our journal! We look forward to hearing from you.

\section{References}

Brundtland, G.H. ed.1987. Our Common Future: The World Commission on Environment and Development. Oxford: Oxford University Press.

Gunder, M. 2006. Sustainability: Planning's saving grace or road to perdition? Journal of Planning Research and Education 26: 208-221 